\title{
A third dose of inactivated vaccine augments the potency, breadth, and duration of anamnestic responses against SARS-CoV-2
}

\author{
Authors: Kang Wang ${ }^{1 \$}$, Yunlong $\mathrm{Cao}^{3 \$}$, Yunjiao $\mathrm{Zhou}^{2 \$}$, Jiajing $\mathrm{Wu}^{4, \$}$, Zijing Jia ${ }^{1 \$}$, Yaling $\mathrm{Hu}^{5 \$}$, \\ Ayijiang Yisimayi ${ }^{3}$, Wangjun $\mathrm{Fu}^{1}$, Lei Wang ${ }^{1}$, Pan Liu ${ }^{1}$, Kaiyue Fan ${ }^{1}$, Ruihong Chen ${ }^{1,6}$, Lin \\ Wang ${ }^{5}$, Jing $\mathrm{Li}^{5}$, Yao Wang ${ }^{3}$, Xiaoqin $\mathrm{Ge}^{5}$, Qianqian Zhang ${ }^{2}$, Jianbo $\mathrm{Wu}^{2}$, Nan Wang ${ }^{1}$, Wei $\mathrm{Wu}^{2}$, \\ Yidan $\mathrm{Gao}^{2}$, Jingyun Miao ${ }^{7}$, Yinan Jiang ${ }^{7}$, Lili Qin ${ }^{7}$, Ling Zhu ${ }^{1}$, Weijin Huang ${ }^{5}$, Yanjun Zhang ${ }^{9}$, \\ Huan Zhang ${ }^{8}$, Baisheng $\mathrm{Li}^{8}$, Qiang $\mathrm{Gao}^{5}$, Xiaoliang Sunney Xie ${ }^{3 *}$, Youchun Wang ${ }^{4 *}$, Qiao \\ Wang $^{2 *}$ and Xiangxi Wang ${ }^{1,6 *}$
}

\section{Affiliation:}

${ }^{1}$ CAS Key Laboratory of Infection and Immunity, National Laboratory of Macromolecules, Institute of Biophysics, Chinese Academy of Sciences, Beijing 100101, China

${ }^{2}$ Key Laboratory of Medical Molecular Virology (MOE/NHC/CAMS), School of Basic Medical Sciences; Shanghai Institute of Infectious Disease and Biosecurity; Shanghai Medical College, Fudan University, Shanghai 200032, China

${ }^{3}$ Beijing Advanced Innovation Center for Genomics (ICG), Biomedical Pioneering Innovation Center (BIOPIC), School of life Science, Peking University, Beijing 100091, China

${ }^{4}$ Division of HIV/AIDS and Sex-transmitted Virus Vaccines, Institute for Biological Product Control, National Institutes for Food and Drug Control (NIFDC), Beijing 102629, China

${ }^{5}$ Sinovac Biotech Ltd, Beijing, China

${ }^{6}$ Guangzhou Laboratory, Guangzhou, Guangdong, China, 510320

${ }^{7}$ Acrobiosystems Inc, Beijing, China

${ }^{8}$ Guangdong Provincial Center for Disease Control and Prevention

${ }^{9}$ Department of Microbiology, Zhejiang Provincial Center for Disease Control and Prevention, Hangzhou, China

*Correspondence to: X.W. (Email: xiangxi@ibp.ac.cn) or Q.W. (Email: wangqiao@fudan.edu.cn) or Y.W. (Email: wangyc@nifdc.org.cn) or X.S.X. (Email: sunneyxie@biopic.pku.edu.cn)

$\$$ These authors contributed equally to this work.

NOTE: This preprint reports new research that has not been certified by peer review and should not be used to guide clinical practice. 
medRxiv preprint doi: https://doi.org/10.1101/2021.09.02.21261735; this version posted September 5, 2021. The copyright holder for this preprint (which was not certified by peer review) is the author/funder, who has granted medRxiv a license to display the preprint in It is made available under a CC-BY 4.0 International license.

\section{Abstract: ( 150 words)}

Emergence of variants of concern (VOC) with altered antigenic structures and waning humoral immunity to SARS-CoV-2 are harbingers of a long pandemic. Administration of a third dose of an inactivated virus vaccine can boost the immune response. Here, we have dissected the immunogenic profiles of antibodies from 3-dose vaccinees, 2dose vaccinees and convalescents. Better neutralization breadth to VOCs, expeditious recall and long-lasting humoral response bolster 3-dose vaccinees in warding off COVID-19. Analysis of 171 complex structures of SARS-CoV-2 neutralizing antibodies identified structure-activity correlates, revealing ultrapotent, VOCsresistant and broad-spectrum antigenic patches. Construction of immunogenic and mutational heat maps revealed a direct relationship between "hot" immunogenic sites and areas with high mutation frequencies. Ongoing antibody somatic mutation, memory B cell clonal turnover and antibody composition changes in B cell repertoire driven by prolonged and repeated antigen stimulation confer development of monoclonal antibodies with enhanced neutralizing potency and breadth. Our findings rationalize the use of 3-dose immunization regimens for inactivated vaccines.

\section{One sentence summary}

A third booster dose of inactivated vaccine produces a highly sifted humoral immune response via a sustained evolution of antibodies capable of effectively neutralizing SARS-CoV-2 variants of concern. 
medRxiv preprint doi: https://doi.org/10.1101/2021.09.02.21261735; this version posted September 5, 2021. The copyright holder for this preprint (which was not certified by peer review) is the author/funder, who has granted medRxiv a license to display the preprint in

\section{Main Text:}

The ongoing coronavirus disease 2019 (COVID-19) pandemic caused by severe acute respiratory syndrome coronavirus-2 (SARS-CoV-2) has lasted for one and a half years, resulting in an unprecedented public health crisis with over 4 million deaths globally. Progress in halting this pandemic seems slow due to the emergence of variants of concern (VOC), such as the B.1.1.7 (Alpha), B.1.351 (Beta), P.1 (Gamma, also known as B.1.1.28.1) and more recent B.1.617.2 (Delta), that appear to be high transmissible and more resistant to neutralizing antibodies (1-4). While several types of COVID-19 vaccines are being deployed at a large scale, new variants are thought to be responsible for re-infections, either after natural infection or after vaccination, as observed in Brazil and the United States, respectively (5, 6). Closely correlated with these, a general decrease in immune protection against SARS-CoV2 variants within 6-12 months after the primary infection or vaccination is also observed (6-8). The prospect of genetic recombination and antigenic drift in recent SARS-CoV-2 variants together with non-uniform immune protections arising from heterogeneously waning humoral immunity in COVID-19 convalescent or vaccinated individuals, point to the potential risks of a long-term pandemic that could endanger the global human health, diminishing social, economic and outdoor leisure activities. A plausible approach to solving this problem is the administration of a third dose of the vaccine somewhere between 6 and 12 months after the 2nd dose of vaccination for enhancing and prolonging the protection. However, not much is known about the immunogenic features of such a booster dose of a COVID-19 vaccine. In addition, there are large gaps in our understanding about correlating immunogenic findings from surrogate endpoints to gauge vaccine efficacy.

The CoronaVac, a 2-dose $\beta$-propiolactone-inactivated vaccine against COVID-19, has been approved for emergency use by the World Health Organization $(9,10)$. In human clinical trials (phase I/II, registration number: NCT04352608), a subgroup with a 3 -dose immunization schedule at months $0,1,7$ was also included. To evaluate immune features, we recruited 22 COVID-19 convalescents, 6 healthy participants (SARS-CoV-2 negative, confirmed by RT-PCR) and 38 volunteers who received 
medRxiv preprint doi: https://doi.org/10.1101/2021.09.02.21261735; this version posted September 5, 2021. The copyright holder for this preprint (which was not certified by peer review) is the author/funder, who has granted medRxiv a license to display the preprint in

It is made available under a CC-BY 4.0 International license.

either 2 or 3 doses of the Coronavac vaccine for blood donation. The volunteers ranged from 16 to 69 years old (median 33); 30 (45.5\%) were men and 36 (54.5\%) were women. None of the volunteers recruited for vaccination was infected by SARS-CoV-2 prior to the study. Blood samples from convalescents and vaccinees collected 1.3 months after infection and the indicated times after vaccination were used in this study, respectively, to compare humoral immune responses elicited against circulating SARS-CoV-2 variants.

Neutralizing antibodies (NAbs) are a major correlate of protection for many viruses, including SARS-CoV-2, and have also provided the best correlate of vaccine efficacy. Several types of SARS-CoV-2 neutralization assays have been described using either live SARS-CoV-2 or a pseudo-typed reporter virus carrying SARS-CoV2 spike protein $(\mathrm{S})$. Both types of assays could yield reproducible neutralizing titers, with the pseudo-typed virus neutralization assay exhibiting higher sensitivity (11, 12). Neutralizing activity of plasma samples from 66 participants was measured against WT, B.1.351, P.1 and B.1.617.2 using live SARS-CoV-2 and VSVpseudoviruses with the S from WT, B.1.1.7, P.1 variants and SARS-CoV (Fig. 1). The geometric mean half-maximal neutralizing titers (GMT NT50) against live SARS-CoV-2 in plasma obtained from convalescents and from vaccinees (4 weeks after the final vaccination) suggest an approximately $60 \%$ higher neutralizing activity against WT after 3-dose inoculation when compared with 2-dose administration, and 20\% higher than those from convalescents (Fig. 1A). Interestingly, for the samples from the convalescents, 2-dose and 3-dose vaccinees, neutralizing titers against B.1.351 were, on average, 7.7-fold, 5.7-fold and 3.0-fold reduced, respectively, compared with WT (Fig. 1A). Similarly, fold decreases in neutralization $\mathrm{ID}_{50}$ titers against P.1 and B.1.617.2 for the three cohorts were 5.3, 4.3 and 3.1, and 5.3, 3.7 and 2.3, respectively (Fig. 1A). Overall, plasma of the 3-dose vaccinees displayed minimal reduction in neutralization titers against several authentic VOCs compared to the convalescents and 2-dose vaccinees (Fig. 1A). Remarkably, $41 \%(9 / 22)$ and 50\% (6/12) samples from the convalescents and 2dose vaccinees, respectively, failed to reach $50 \%$ neutralization at a plasma dilution 
medRxiv preprint doi: https://doi.org/10.1101/2021.09.02.21261735; this version posted September 5, 2021. The copyright holder for this preprint (which was not certified by peer review) is the author/funder, who has granted medRxiv a license to display the preprint in

of 1: 10, with $\sim 14 \%(3 / 22)$ and $16 \%(2 / 12)$ showing a near ineffectiveness in neutralizing B.1.351 in vitro (Fig. 1A). By contrast, only 1 out of 14 samples from the 3-dose vaccinees exhibited a weak neutralizing titer below 10 (Fig. 1A). Importantly, the 3-dose vaccinees showed over 2.5-fold higher neutralizing potency against B.1.617.2 than the convalescents and 2-dose vaccinees (Fig. 1A). The GMT $\mathrm{NT}_{50}$ values measured by a VSV-pseudovirus with the WT S were 840, 660 and 1,176 for convalescents, 2-dose and 3-dose vaccinees, respectively, which were 8-10-fold greater than those determined by live WT SARS-CoV-2 (Fig. 1A, 1B), confirming higher sensitivity of pseudovirus-based assays in determining neutralizing titers. In line with the results of live SARS-CoV-2 neutralization assay, the mean fold decrease in the neutralization of B.1.1.7 relative to the WT was 2.8-fold for convalescents, 2.2-fold for 2-dose vaccinees and 1.7-fold for 3-dose vaccinees (Fig. 1B). Similarly, plasma from convalescents, 2-dose and 3-dose vaccinees exhibited a 4.5-fold, 2.9fold and 2.4-fold reduction, in NAb titers against P.1, respectively, when compared to the WT (Fig. 1B). These results reveal that a third-dose boost of inactivated vaccine leads to enhanced neutralizing breadth to SARS-CoV-2 variants, bolstering the potential to ward off VOCs effectively when compared to convalescent plasma. Of note, neither vaccination nor SARS-CoV-2 infection boosts distinct neutralizing potency against SARS-CoV, presumably due to the relatively far phylogenic relationship (Fig. 1B).

To seek information on potential binding-neutralization correlates, the abilities of antibodies present in plasma to bind the receptor-binding domain (RBD), N-terminal domain (NTD), S-trimer and nucleoprotein (N) from SARS-CoV-2 and its variants were measured by enzyme-linked immunosorbent assay (ELISA). As expected, all COVID-19 convalescents and vaccinees exhibited high anti-RBD, anti-NTD, anti-S and anti-N titers for SARS-CoV-2 variants, but weak antibody reactivity to SARS$\mathrm{CoV}$ (Fig. 1C and fig. S1). Unexpectedly, the amount of N-specific IgG elicited by 2-dose and 3-dose vaccination schedules was 2-6-fold lower than those of convalescents, and 2-6-fold lower than the antibodies targeting $\mathrm{S}$ or RBD in vaccinees, reflecting distinct serological profiles (Fig. 1C and fig. S1). Overall 
medRxiv preprint doi: https://doi.org/10.1101/2021.09.02.21261735; this version posted September 5, 2021. The copyright holder for this preprint (which was not certified by peer review) is the author/funder, who has granted medRxiv a license to display the preprint in

plasma neutralizing activity against the WT was substantially correlated with anti-S and anti-RBD binding titers in ELISA. However, only marginal correlates between binding and neutralization potency were established for VOCs (fig. S2). In spite of this, a 3-dose administration elicits a broader range of antibody binding activities to VOCs with minimal decreasing folds than those of 2-dose vaccination and convalescents (Fig. 1D and fig. S2).

To evaluate the nature of humoral immune response elicited by a booster dose of CoronaVac, the S-specific IgA, IgM and IgG titers and neutralizing activities against SARS-CoV-2 variants were monitored before and 4 weeks after the third immunization. S-specific $\operatorname{IgM}$ and $\operatorname{IgA}$ titers were generally lower and were not significantly boosted in response to the third-dose vaccination (Fig. 1E). Similar to most convalescents (2), approximately $80 \sim 90 \%$ of both anti-S IgG and NAb titers against the WT waned 6 months after the second vaccination (13), while the thirddose administration of CoronaVac boosted these titers by $\sim 20$-fold at 4 weeks post vaccination (Fig. 1E and F). Significantly, vaccinees 6 months after the second immunization did not have detectable in vitro neutralizing activities against B.1.351, P.1 and B.1.617.2, while all vaccinees exhibited a robust recall humoral response to efficiently neutralize circulating variants post the third-dose vaccination (Fig. 1E and F). To further characterize the expeditiousness, longevity and immunological kinetics of recall response stimulated by the third-dose immunization, neutralizing potencies at days $0,7,14,28,90$ and 180 post the third-dose vaccination were determined (Fig. $1 \mathrm{G}$ and H). Remarkably, NAb titer surged by $\sim 8$-fold (from 7 to 53) at week 1 , peaked by $\sim 25$-fold increase (up to 177) at week 2 after the $3^{\text {rd }}$-booster and slowly decreased over time (Fig. 1G). Notably, NAb titer was maintained at around 60 on 180 days post the $3^{\text {rd }}$-booster, comparable to the high level of NAb titer elicited by the 2-dose administration (Fig. 1H). Taken together, these serological results reveal a third-dose booster can elicit an expeditious, robust and long-lasting recall humoral response. 
medRxiv preprint doi: https://doi.org/10.1101/2021.09.02.21261735; this version posted September 5, 2021. The copyright holder for this preprint (which was not certified by peer review) is the author/funder, who has granted medRxiv a license to display the preprint in

It is made available under a CC-BY 4.0 International license.

184

185

186

187

188

189

190

191

192

193

194

195

196

197

198

199

200

201

202

203

204

205

206

207

208

209

210

211

212

213

214

responses elicited by a third-dose booster 6 months after the administration of the second dose of the vaccine, might involve ongoing antibody somatic mutation and evolution of antibody by affinity maturation through prolonged and repeated antigen stimulation $(14,15)$. Although circulating antibodies derived from plasma cells wane over time, long-lived immune memory can persist in expanded clones of memory B cells (16). Thereby, we used flow cytometry to sort the SARS-CoV-2 S-trimerspecific memory B cells from the blood of seven selected CoronaVac vaccinees, including four samples from 3-dose vaccinees and three samples from 2-dose vaccinees (Fig. 2A and fig. S3). The averaged percentage of S-binding memory B cells in 3-dose vaccinees was substantially greater than those in 2-dose vaccinees (Fig. 2A and fig. S3). Due to differences in labeling strategies employed for sorting SARS-CoV-2-specific B cells, the above percentage of memory B cells was not directly comparable with those reported in naturally infected individuals and in mRNA vaccinated individuals. The gated double-positive cells were single cell sorted and immunoglobulin heavy ( $I G H$; IgG isotype) and light (IGL or $I G K)$ chain genes were amplified by nested PCR. Overall, we obtained 422 and 132 paired heavy and light chain variable regions from S-binding $\mathrm{IgG}^{+}$memory B cells from four 3dose and three 2-dose vaccinees, respectively (Fig. 2B and fig. S4). Surprisingly, expanded clones of cells comprised $45-61 \%$ of the overall S-binding memory B compartment in 3-dose vaccinees, which is approximately 2 -fold higher than those in COVID-19 convalescents and in mRNA or 2-dose vaccinated individuals (Fig. 2B and C). When compared to 2-dose vaccinees, the increase in the number of persistent clones and various clonal compositions in 3-dose vaccinated group suggested an ongoing clonal evolution (Fig. 2B and C). Shared antibodies with the same combination of $I G H V$ and $I G L V$ genes in 3 -dose vaccinees comprised $\sim 20 \%$ of all the clonal sequences. Similar to natural infection and mRNA vaccination $(2,14,16)$, IGHV3-30, IGHV3-53 and IGHV1-69 remained significantly over-represented in 3dose vaccinees (fig. S5). Meanwhile, notable differences in the frequency of human $\mathrm{V}$ genes between 3-dose vaccinated and the other two groups were observed as well (fig. S5). In 3-dose vaccinees, IGHV3-21, IGHV4-39 and IGHV7-4-1 were largely abundant, but IGHV5-51,IGHV3-66 and IGHVI-2 were significantly scarce when 
medRxiv preprint doi: https://doi.org/10.1101/2021.09.02.21261735; this version posted September 5, 2021. The copyright holder for this preprint (which was not certified by peer review) is the author/funder, who has granted medRxiv a license to display the preprint in

It is made available under a CC-BY 4.0 International license.

compared to the other two groups (fig. S5), indicative of memory B cell clonal turnover. Notably, large-scale, single-cell sequencing datasets generated from two cohorts of 2-dose, 3-dose vaccinees and a group of convalescents revealed no distinct preference in the frequency of $V$ genes at total B cell repertoire level (fig. S6), suggesting that a large abundance of antibodies with low expression or affinities exist in B cells. Additionally, the number of nucleotide mutations in the $V$ gene in 3-dose vaccinees is higher than those in both 2-dose vaccinees and naturally infected individuals assayed after 1.3 and 6.2 months, but slightly lower than those in convalescent individuals 1 year after infection (Fig. 2D), revealing ongoing somatic hypermutation of antibody genes. There was no significant difference in the length of the IgG CDR3 between vaccinated (either mRNA or inactivated) and convalescent (after 1.3 or 6.2 or months) groups (fig. S7). These results reveal that a third-dose booster 6 months after the second vaccination elicits an enhanced and anamnestic immune response, which is led by clonal evolution of memory B cell and ongoing antibody somatic mutations, resulting in enhanced neutralizing potency, breadth and longevity of the immune response against SARS-CoV-2.

To further explore the immunogenic characteristics of the antibodies obtained from memory B cells in 3-dose vaccinees, 48 clonal antibodies, designated as XGv01 to XGv50 (no expression for XGv37 and XGv48) were expressed and their antigen binding abilities verified by ELISA (fig. S8). Biolayer interferometry affinities (BLI) measurements demonstrated that all antibodies bound to WT SARS-CoV-2 at subnM levels (fig. S9 and table S1). The normalized geometric mean ELISA halfmaximal concentration $\left(\mathrm{EC}_{50}\right)$ revealed that all antibodies $\left(\mathrm{EC}_{50}=4.5 \mathrm{ng} / \mathrm{ml}\right)$ obtained from 3-dose vaccinees, in particular RBD-specific $\mathrm{mAbs}\left(\mathrm{EC}_{50}=3.5 \mathrm{ng} / \mathrm{ml}\right)$, possessed higher binding activities than RBD-mAbs from early convalescents (at 1.3 and 6.2 months after infection, $\mathrm{EC}_{50}=5.0$ and $6.8 \mathrm{ng} / \mathrm{ml}$, respectively) and mRNA $\left(\mathrm{EC}_{50}=4.4 \mathrm{ng} / \mathrm{ml}\right)$ vaccinated individuals $(2,14-18)$, but were comparable to those from late convalescent individuals $\left(\mathrm{EC}_{50}=2.6 \mathrm{ng} / \mathrm{ml}\right)$ assessed at 12 months after infection (Fig. 2E). These results indicate the possibility of the loss of antibodies with low binding affinities over time or an ongoing increase in affinity under the 
medRxiv preprint doi: https://doi.org/10.1101/2021.09.02.21261735; this version posted September 5, 2021. The copyright holder for this preprint (which was not certified by peer review) is the author/funder, who has granted medRxiv a license to display the preprint in

It is made available under a CC-BY 4.0 International license.

repeated exposures of antigen. Among these antibodies tested, 26 bound to RBD, 16 targeted NTD, and 6 interacted with neither RBD nor NTD, but bound S1 (S1/nonRBD-NTD) (fig. S9 and table S1). Pseudovirus neutralization assay revealed that all RBD-specific antibodies, $10(\sim 60 \%)$ of the 16 NTD-directed antibodies and 3 $(\sim 50 \%)$ of the $6 \mathrm{~S} 1 /$ non-RBD-NTD antibodies were neutralizing, presenting a relatively high ratio for NAbs (Fig. 2F, fig. S10 and table S2). Authentic SARS-CoV2 neutralization assay results largely verified their neutralizing activities, albeit with that higher concentrations were required for some NAbs (fig. S11). Compared to RBD antibodies, many NTD NAbs exhibited very limited neutralizing activities. Notably, approximately 30\% of RBD antibodies showed extra potent activities with half-maximal inhibitory concentration values $\left(\mathrm{IC}_{50}\right)<0.1 \mathrm{nM}$. In line with binding affinity, the normalized geometric mean $\mathrm{IC}_{50}$ of the $\mathrm{RBD}$ antibodies of 3-dose vaccinees was $80 \mathrm{ng} / \mathrm{ml}$, substantially lower than those from naturally infected individuals (ranging from 1.3 to 6.2 months, $\mathrm{IC}_{50}=130-160 \mathrm{ng} / \mathrm{ml}$ ) and mRNA vaccinated individuals $\left(\mathrm{IC}_{50}=150 \mathrm{ng} / \mathrm{ml}\right)$, but similar to those from late convalescents $\left(\mathrm{IC}_{50}=78 \mathrm{ng} / \mathrm{ml}\right)$ (Fig. 2E) (2, 14-18). The overall increased neutralizing potency might have resulted from the ongoing accumulation of clones expressing antibodies with tight binding and potent neutralizing activities. Our experimental observations are consistent with a more recent study where antibodies generated from clonal B cells after 12 months showed enhanced neutralizing activities $(14,15)$.

To examine the cross-reactivity against VOCs and other human coronaviruses, binding responses of these antibodies to WT, B.1.1.7, P.1, B.1.351, B.1.617.2, SARSCoV, HuCoV NL63, HuCoV 229E and HuCoV HKU1 were measured. All but 2 of the 48 antibodies showed strong cross-binding to SARS-CoV-2 VOCs and about onethird of antibodies exhibited clear cross-reactivity to SARS-CoV, but none of these bound to $\mathrm{HuCoV}$ NL63, HuCoV 229E or HuCoV HKU1 (fig. S12). For 20\% and $25 \%$ of RBD- and NTD-targeting antibodies, respectively, binding affinities against B.1.351/B.1.617.2 were over 10-fold reduced compared with WT (Fig. 2E). To further determine the neutralization breadth, the neutralizing activity of these antibodies was assayed against five VOCs and SARS-CoV. Out of 26 RBD NAbs, 
medRxiv preprint doi: https://doi.org/10.1101/2021.09.02.21261735; this version posted September 5, 2021. The copyright holder for this preprint (which was not certified by peer review) is the author/funder, who has granted medRxiv a license to display the preprint in 2F and fig. S13). Among these, six RBD antibodies could cross-neutralize SARS$\mathrm{CoV}$, of which 2 exhibited more potent neutralization activity against SARS-CoV with $\mathrm{IC}_{50}$ values of 41 and $73 \mathrm{ng} / \mathrm{ml}$. However, most of the NTD and S1/non-RBDNTD NAbs lost their abilities to inhibit viral infection (Fig. 2F and fig. S13), indicative of higher variations for the NTD in VOCs. In comparison with NAbs from early convalescents, antibodies isolated from 3-dose vaccinees showed overall enhanced neutralizing potency and breadth to VOCs.

RBD is one of the main targets of neutralization in SARS-CoV-2 and other coronaviruses. Due to its inherent conformational flexibility, RBD exists in either an "open" (ACE2 receptor accessible) or "closed" (ACE2 receptor inaccessible) configuration $(19,20)$, bearing antigenic sites with distinct "neutralizing sensitivity". To dissect the nature of the epitopes of RBD targeted by NAbs, 171 SARS-CoV-2 RBD-targeting NAbs with available structures $(2,15,21-82)$, including 8 cryo-EM structures determined in this manuscript (fig. S14-S15 and table S3), were examined. By using cluster analysis on epitope structures, the antibodies were primarily classified into six sites (I, II, III, IV, V and VI) (Fig. 3A and fig. S16), that are related to the four or five classes assigned in recent studies $(22,31)$. Additionally, we superimposed structures of RBDs from these complex structures and calculated the clash areas between any 2 NAbs (Fig. 3B). Both strategies yielded identical results. Combining the results of the characterization of binding and neutralization studies reported previously with those determined here, the key structure-activity correlates for the six classes of antibodies were analyzed (Fig. 3). Antibodies with sites I, II and III, most frequently elicited by SARS-CoV-2 early infection, target the receptorbinding motif (RBM), and potently neutralize the virus by blocking the interactions between SARS-CoV-2 and ACE2 (Fig. 3C and D). Class I antibodies, mostly derived from IGHV3-53/IGHV3-66 with short HCDR3s (generally $<15$ residues), recognize only the "open" RBD, and make contact with K417 and N501, but not L452/T478/E484 (Fig. 3C and D, and fig. S16-S17). Notably, mutations such as 
medRxiv preprint doi: https://doi.org/10.1101/2021.09.02.21261735; this version posted September 5, 2021. The copyright holder for this preprint (which was not certified by peer review) is the author/funder, who has granted medRxiv a license to display the preprint in

It is made available under a CC-BY 4.0 International license.

identified in several VOCs like B.1.1.7, B.1.617.2, P.1 and B.1.351, have been demonstrated to be key determinants for the viral escape of neutralization by many NAbs (fig. S18) $(1,81)$. Approximately $\sim 75 \%$ and $60 \%$ of class I NAbs were significantly impaired in binding and neutralizing activities against B.1.351 as well as P.1, respectively, due to the combined mutations of K417N/T and N501Y (Fig. 3D and E, and fig. S18). Contrarily, Class III antibodies that are encoded by IGHV1-2 and other variable heavy (VH)-genes and bound to RBD either in "open" or "closed" conformation, extensively associate with E484, and partially with L452, but not K417/T478/N501 (Fig. 3D and fig. S17C). Interestingly, IGHV3-53/IGHV3-66 RBD antibodies with long HCDR3s ( $>15$ residues) switch their epitopes from the site I to site III, indicating a clear antigenic drift during the process of somatic hypermutations (fig. S17C). Disastrously, over 90\% class III antibodies showed a complete loss of activity against B.1.351 as well as P.1 largely owing to an E484K mutation (Fig. 3E). Against B.1.617.2, the substantially decreased activity of $\sim$ half of the class III antibodies is presumably mediated by L452R (Fig. 3E). Class II antibodies use more diverse VH-genes and target the patch lying between sites I and III (Fig. 3D and fig. S19). Surprisingly, antibodies binding to site II possess relatively lower specificity in recognition of epitope clusters ranging from K417, L452, S477, E484 to N501 (fig. S16). Like site I, site II can only be accessed when the RBD is in "open" conformation (Fig. 3A). As expected, the effects of mutations on the activity of class II antibodies were severe, two-thirds of these antibodies had $>10$-fold fall in neutralization activities against VOCs (Fig. 3E). Overall, the above analysis reveals that the RBD mutations identified in several VOCs can significantly reduce and, in some cases, even abolish the binding and neutralization of classes I to III antibodies, albeit being the most potent neutralizing antibodies against WT SARS-CoV-2.

By contrast, antibodies of the other three classes recognize evolutionarily conserved regions distinct from the RBM and some of these are often cross-reactive with other sarbecoviruses $(65-67,79)$. The binding of class IV antibodies, albeit attached to the apical shoulder of the RBM, is focused on a condensed patch that comprises residues 345-346, 440-441, 444-446, 448-450, which are not related to mutations observed in 
medRxiv preprint doi: https://doi.org/10.1101/2021.09.02.21261735; this version posted September 5, 2021. The copyright holder for this preprint (which was not certified by peer review) is the author/funder, who has granted medRxiv a license to display the preprint in

339 VOCs (Fig. 3C and fig. S16). Related to the binding position, site IV epitopes, 340 accessible in both "open" and "closed" conformations, exist either as partially 341 overlapped with or outside ACE2 binding sites (Fig. 3A). Interestingly, class IV 342 antibodies can execute their neutralizations via multiple mechanisms, such as (i) 343 direct blockage of RBD-ACE2 associations, (ii) bridging adjacent "closed" RBDs to 344 lock the S-trimer into a completely closed prefusion conformation, (iii) blockage of 345 viral membrane fusion by locking conformational changes of the S-trimer, or (iv) Fc346 dependent effector mechanisms (31, 62, 67). Class IV antibodies, e.g. 1-57, 2-7, S309 347 and BD-812, hold the greatest potential for harboring ultra-potent neutralization 348 activity and markedly high tolerance to most VOCs $(63,67)$. Not surprisingly, all class 349 IV antibodies, but CV07-270, exhibited excellent neutralizing breadth and potency to 350 VOCs (Fig. 3E). The probable reason underlying the exception could be that CV07351270 bears an unusually long HCDR3, directly contacting E484, distal to the site IV (46). 352 Site V locates beneath the RBM ridge, opposite to the site I, and adjacent to the site 353 III. None of the class V antibodies compete with ACE2 binding (Fig. 3D and fig. $354 \mathrm{~S} 17$ ). Due to $\sim 40 \%$ targeting frequency to L452, B.1.617.2, but not other VOCs, 355 partially decreased the activities of some class V antibodies (Fig. 3E). Class VI 356 antibodies recognize a patch on one side of the RBD, distal from the RBM. Among 357 these, some compete with ACE2 binding, while some do not, and this largely depends on the orientation/pose of the antibodies bound. Both sites V and VI contain cryptic epitopes that are only accessible when at least one RBD is in the open state (Fig. 3A and C). In some cases, e.g. FC08 and CR3022, belonging to class V and VI, respectively, epitopes are only accessible in the prefusion S-trimer under the condition that all RBDs are open, suggesting that binding of these antibodies would facilitate the destruction of the prefusion S-trimer $(83,84)$. In spite of less potency, antibodies targeting sites V to VI are mostly tolerant to the VOCs.

Low levels of NAbs elicited by either natural infection or vaccination during in vivo viral propagation may impose strong selection pressure for viral escape, leading to an increase in the number of SARS-CoV-2 variants. To further understand the drivers of viral evolution, we constructed immunogenic and mutational heatmaps for RBD 
medRxiv preprint doi: https://doi.org/10.1101/2021.09.02.21261735; this version posted September 5, 2021. The copyright holder for this preprint (which was not certified by peer review) is the author/funder, who has granted medRxiv a license to display the preprint in

using the $171 \mathrm{NAb}$ complex structures to estimate in vivo NAb-targeting frequencies on the RBD and viral mutation frequencies (calculated from the datasets in the GISAID), respectively (Fig. 3D and fig. S19). Briefly, for each antibody, we identified epitope residues and calculated the frequency of each RBD residue being recognized by antibody. Immunogenic heatmap revealed that the epitope residues of sites I to III showed predominantly higher NAb recognition frequencies (about 53.8, 55.0 and 49.2 antibodies per residue on average for site I, II and III, respectively) compared with those of sites IV to VI (about 19.4, 9.1 and 14.3 antibodies per residues on average for site IV, V and VI, respectively), suggesting that class I to III antibody epitopes are "hot" immunogenic sites (Fig. 3D and fig. S19). In line with this, residues within sites I to III exhibited dramatically higher mutation frequencies, as revealed in circulating variants that include mutations of K417, L452, S477, T478, E484 and N501 residues (Fig. 3D and fig. S19). Surprisingly, none of the top 9 hottest immunogenic residues had a high mutation frequency. In particular, residues, such as F486, Y489, Q493, L455, F456, et.al (top 5, having 96, 96, 81, 73 and 70 antibodies per residue, respectively) with large side chains exhibited extremely low mutation frequencies in circulating SARS-CoV-2 strains (Fig. 3D and fig. S20). It's worthy to note that all these residues are extensively involved in the recognition of ACE2. The buried surface area (BSA) of these residues upon binding to ACE2 confirmed that extensive interactions would be significantly reduced by amino acid substitutions, thereby affecting ACE2-mediated viral entry. Thus, genetic, structural and immunogenic analysis explains why mutations at these positions would not be selected.

A few studies have reported that a subset of NTD-targeting antibodies can be as potent as best-in-class RBD specific antibodies. They work via inhibiting a step postattachment to cells like blocking fusion of the virus to the host cell membrane (8588). We performed cluster analysis on 26 structures of the NTD-NAb complexes (including 2 structures solved in this manuscript) (fig. S21A) (54, 85-93). A dominant site $\alpha$, defined as the "supersite" in more recent studies (85-88), comprising 
medRxiv preprint doi: https://doi.org/10.1101/2021.09.02.21261735; this version posted September 5, 2021. The copyright holder for this preprint (which was not certified by peer review) is the author/funder, who has granted medRxiv a license to display the preprint in

facing away from the viral membrane (facing up). Antibodies targeting site $\alpha$ generally exhibited the most potent neutralizing activity compared to other sites on the NTD $(85,90)$ (fig. S21B and C). The NTD supersite antibodies are primarily derived from a subset of VH-genes with an over-representation of IGHV1-24. Sites $\beta$ and $\gamma$, as the left and right flank clusters, construct a shallow groove beneath the supersite and locate at the back of the groove, eliciting less potent antibodies. By contrast, $\delta$ antibodies, bound to a patch beneath the groove have their Fab constant domains directed downward toward the virus membrane (facing down) (fig. S21B and C). In line with binding orientation, many of the $\delta$ antibodies were shown to present infection enhancing activities in vitro $(54,90)$. Perhaps correlated with being a "hot" immunogenic site that is amenable to potent neutralization, highly frequent mutations, including a number of deletions within the NTD supersite were identified in most VOCs under ongoing selective pressure, leading to significant reduction and in some cases even complete loss of neutralization activity for these NTD supersite NAbs (94).

More recent studies have reported that SARS-CoV-2 infection can produce a longlasting memory compartment that continues to evolve over 12 months after infection with ongoing accumulation of somatic mutations, emergence of new clones and increasing affinity of antibodies to antigens $(14,15)$. Consequently, an increase in breadth and overall potency of antibodies produced by memory B cells over time has been revealed (14), akin to the experimental observations elicited by a 3-dose vaccination strategy using an inactivated vaccine described in this study. To investigate whether changes in the frequency of distribution of the six types of RBD antibodies is associated with evolution time, we collated and categorized human SARS-CoV-2 NAbs from available literatures. For antibody clustering, we combined structural and square competition matrix analysis for 273 RBD NAbs in total (Fig. 4A and fig. S22). In the earliest documented studies (before Dec 2020), NAbs belonging to classes I to III were predominantly identified in early COVID-19 convalescent and 2-dose vaccinated individuals (defined as early time point), accounting for up to $\sim 80 \%$ of total antibodies. By contrast, a low ratio of NAbs from 
medRxiv preprint doi: https://doi.org/10.1101/2021.09.02.21261735; this version posted September 5, 2021. The copyright holder for this preprint (which was not certified by peer review) is the author/funder, who has granted medRxiv a license to display the preprint in

It is made available under a CC-BY 4.0 International license .

432 IV to VI was reported possibly due to their less potent activities at the early time 433 point (Fig. 4A). In recent literatures (after Dec 2020), NAbs with enhanced 434 neutralizing potency and breadth from IV to VI have substantially been enriched in 435 the late convalescents or 3-dose vaccinees, almost equal in frequency to antibodies 436 from I to III and further becoming ascendant in individuals immunized with 3 doses 437 of inactivated vaccine (Fig. 4A). Differential frequency of distribution of antibody 438 types may provide an additional possible explanation for the observed enhanced 439 neutralizing breadth of plasma in late convalescent individuals and 3-dose vaccinees. 440 These results suggest that memory B cells display clonal turnover after about 6 441 months, subsequently resulting in changes in the composition of antibodies in B cell 442 repertoire and thereby partially contributing to enhanced activities of antibodies 443 secreted in the plasma over time. To explore the underlying mechanism, we measured 444 the binding affinities of 167 type-classified antibodies that are also further 445 categorized into early and late time point groups (table S1 and fig. S9). For the late time group, there was a 10-20 fold increase in binding affinity for individual classes, compared to those in the early time point group (Fig. 4B). In early time point group, antibodies from IV to VI exhibited higher binding affinities to the RBD than those from I to III, in particular, antibodies from V and VI despite limited numbers (Fig. 4B). Possibly higher affinities for these antibodies are required to accomplish neutralization successfully. Thus, most antibodies from V and VI with low affinities and activities might be screened out in the early time point. In the late point group, sub- $n M$ binding affinities for individual class antibodies with no distinct variations were observed, reflecting ongoing affinity maturation over time. This might also explain the observation that some antibodies, from I to III isolated in the late time point possess potent cross-neutralization activities (Fig. 3E). Our antibody clustering and $V$ gene usage analysis suggests that individual class antibodies can be derived from multiple $V$ genes and the shared $V$ gene antibodies belong to different classes. To decipher the intrinsic trends in the relationship between binding affinity and somatic hypermutation (SHM) rate, we determined the relative affinity $\left(K_{D}\right)$ and calculated the SHM rate of antibodies that are encoded by the same $V$ gene and belong to the same class. The measured $K_{D}-\mathrm{SHM}$ plots and $K_{D}-\mathrm{SHM} \log -\log$ plots of 
medRxiv preprint doi: https://doi.org/10.1101/2021.09.02.21261735; this version posted September 5, 2021. The copyright holder for this preprint (which was not certified by peer review) is the author/funder, who has granted medRxiv a license to display the preprint in perpetuity.

It is made available under a CC-BY 4.0 International license.

class I antibodies ( $\mathrm{n}=61$ ), including 32 NAbs derived from IGHV3-53, show least squares fitting of data to a power law with a strong correlation of -0.81 for IGHV3-53 antibodies (-0.55 for all class I antibodies) (Fig. 4C). The absolute value of its slope corresponding to a free energy change per logarithm (base e) $S H M$ of cal nmol-1, where free energy change is $4.98 R T+1.48 R T \ln (S H M)\left(R=2.0 \mathrm{cal} \mathrm{K}^{-1} \mathrm{nmol}^{-1}\right.$ and $T=298 \mathrm{~K}$ ). Antibodies with adequate numbers tested from II and III exhibited similar trends by following a power law, among which IGHV3-66 antibodies in class II yielded a compelling correlation of -0.94 despite 6 plots involved in the fitting (Fig. 4C). These trends indicate that as the SHM increase, the binding energy increases and $K_{D}$ value decreases.

More recently, the B.1.617.2 variant has contributed to another surge in COVID-19 cases worldwide, accounting for $\sim 90 \%$ of new cases in the UK and $>40 \%$ in the US, despite the fact that increasing number of people have been vaccinated. Evaluation of the effectiveness of several vaccines performed recently suggests that the efficacy for VOCs correlates with full vaccination status and the time that has passed since vaccination $(95,96)$. These may indicate that the effectiveness of the vaccines has started to decline as months pass after vaccination due to fading immunity. Our results demonstrate that a third-dose booster of inactivated vaccine can elicit an expeditious, robust and long-lasting recall humoral response which continues to evolve with ongoing accumulation of somatic mutations, emergence of new clones and increasing affinities of antibodies to antigens, conferring enhanced neutralizing potency and breadth. Collectively, our findings rationalize the use of 3-dose vaccination regimens.

Acknowledgments: We thank Dr. Xiaojun Huang, Dr. Boling Zhu, Dr. Lihong Chen, Dr. Xujing Li and Dr. Gang Ji for cryo-EM data collection, the Center for Biological Imaging (CBI) in Institute of Biophysics for EM work and thank Dr. Yuanyuan Chen, Zhenwei Yang for technical help with BLI experiments. We also thank Prof. David Ho and Prof. Barton Ford Haynes for generous gift of the sequences of two reference mAbs. Work was supported by the Strategic Priority Research Program 
medRxiv preprint doi: https://doi.org/10.1101/2021.09.02.21261735; this version posted September 5, 2021. The copyright holder for this preprint (which was not certified by peer review) is the author/funder, who has granted medRxiv a license to display the preprint in perpetuity.

It is made available under a CC-BY 4.0 International license .

495

496

497

498

499

500

501

502

503

504

505

506

507

508

509

510

511

512

513

514

515

516

517

518

519

520

521

522

523

524

525

(XDB29010000, XDB37030000), CAS (YSBR-010), National Key Research and Development Program (2020YFA0707500, 2018YFA0900801), Emergency Key Program of Guangzhou Laboratory, Grant No. EKPG21-09 and Beijing Municipal Science and Technology Project (Z201100005420017). Xiangxi Wang was supported by Ten Thousand Talent Program and the NSFS Innovative Research Group (No. 81921005). Author contributions: X.W., Q.W., Y.W., X.S.X and Y.C. conceived, designed and coordinated the experiments. Y.Z., A.Y., Y.W., Q.Z. and J-B.W. cloned and produced antibodies. K.W., Z.J., K.F., J.M., Y.J. and L.Q. expressed and purified all recombinant antigen proteins used in this manuscript. J-J.W., Y.H., L.W., J.L., X.G., Y-J.Z., H.Z. and B-S.L performed pseudovirus and authentic virus neutralization experiments. K.W., L.W., P. L., WJ.F, N.W and L.Z performed structural study. Y.C., Y.Z., W.W. and Y.G. prepared PBMCs and flow cytometry sorting. Y.C. and A.Y. performed 10X sequencing library construction. Z.J. and K.F performed BLI assay. Y.H. and Q.G recruited volunteers and coordinated the collection of blood samples. All authors analyzed data; X.W wrote the manuscript with input from all authors. Competing interests: All authors have no competing interests. Data and materials availability: Cryo-EM density maps of the SARS-CoV-2 S trimer in complex with XGv013 or XGv043, the SARS-CoV-2 S trimer in complex with XGv004, XGv030 and XGv016; the SARS-CoV-2 S trimer in complex with XGv026 and XGv046, and the SARS-CoV-2 S trimer in complex with XGv018, XGv038 and XGv42 have been deposited at the Electron Microscopy Data Bank with accession codes EMD-UUUU, EMD-WWWW, EMD-XXXX, EMD-YYYY and EMD-ZZZZ, respectively. .

(

.

(1)



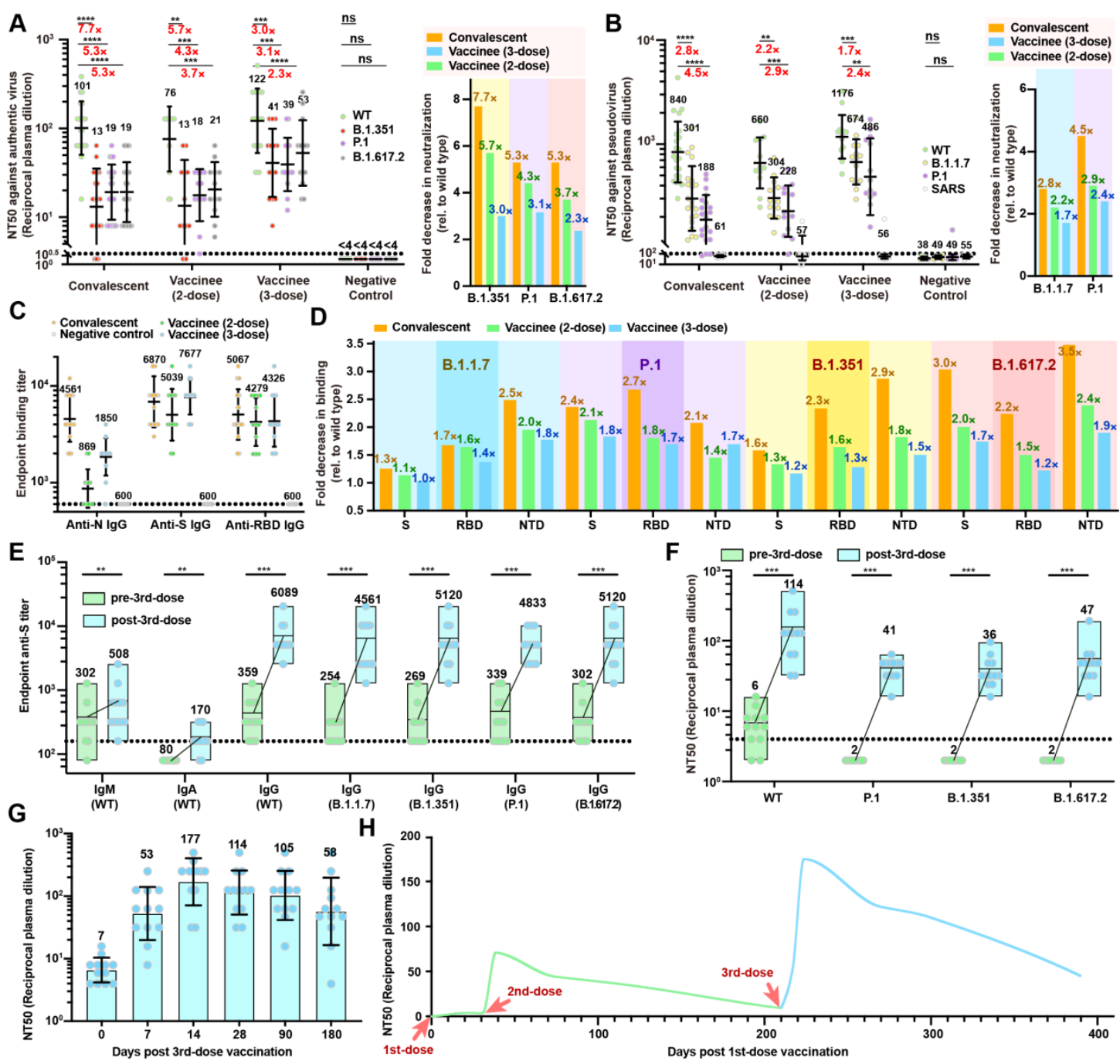

Fig. 1 A $3^{\text {rd }}$-dose booster of an inactivated vaccine elicits an expeditious and

529 Plasma neutralizing activity evaluated by authentic SARS-CoV-2 (A) and pseudotyped SARS-CoV-2 neutralization assays (B) Left: half-maximal neutralizing titer

531 (NT 50$)$ values for plasma from COVID-19 convalescents, 2-dose, 3-dose CoronaVac vaccine recipients (at week 4 after the last dose of vaccination) and negative controls (pre-COVID-19 historical control) against live SARS-CoV-2 WT, B.1.351, P.1 and B.1.617.2, and VSV-based SARS-CoV-2 pseudoviruses bearing WT or B.1.1.7 or P.1 $\mathrm{S}$ protein. Black bars and indicated values represent geometric mean $\mathrm{NT}_{50}$ values. Statistical significance was determined using the two-tailed Wilcoxon matched-pairs test. Experiments were repeated in triplicate. Dotted lines indicate the limit of detection. Right: fold decrease in neutralization for each variant relative to WT for 
medRxiv preprint doi: https://doi.org/10.1101/2021.09.02.21261735; this version posted September 5, 2021. The copyright holder for this preprint (which was not certified by peer review) is the author/funder, who has granted medRxiv a license to display the preprint in It is made available under a CC-BY 4.0 International license.

539 each cohort of plasma samples (calculated from the left datasets) is shown.

540 (C) IgG endpoint antibody responses specific to the N, RBD and S of WT SARS-

541 CoV-2 were measured in plasma samples collected from cohorts as described earlier.

542 (D) Fold decrease in specific binding to the RBD, NTD and S for each variant over

543 WT for each cohort of plasma samples as described above.

544 (E) IgA, IgM and IgG endpoint antibody titers specific to the S of WT SARS-CoV-

5452 or its variants in plasma samples collected from vaccinees before and 4 weeks after 546 the $3^{\text {rd }}$-dose immunization.

547 (F) Neutralizing titers against live SARS-CoV-2 WT, P.1, B.1.351 and B.1.617.2 for 548 plasma from vaccinees before and 4 weeks after the $3^{\text {rd }}$-dose immunization. Black 549 bars and indicated values represent geometric mean $\mathrm{NT}_{50}$ values.

550 (G) Longitudinal neutralizing titers of plasma from 3-dose vaccinees at days 0, 7, $55114,28,90$ and 180 post the $3^{\text {rd }}$-dose vaccination. The geometric mean $\mathrm{NT}_{50}$ values 552 are labeled.

553 (H) Kinetics of the $3^{\text {rd }}$-dose booster elicited recall response as indicated during 554 monitoring of NAb titers at different time points. The green and blue curves show 555 the changes in kinetics of NAb titers for pre- $3^{\text {rd }}$-dose and post- $3^{\text {rd }}$-dose vaccination, 556 respectively. 
medRxiv preprint doi: https://doi.org/10.1101/2021.09.02.21261735; this version posted September 5, 2021. The copyright holder for this preprint (which was not certified by peer review) is the author/funder, who has granted medRxiv a license to display the preprint in perpetuity.

It is made available under a CC-BY 4.0 International license.

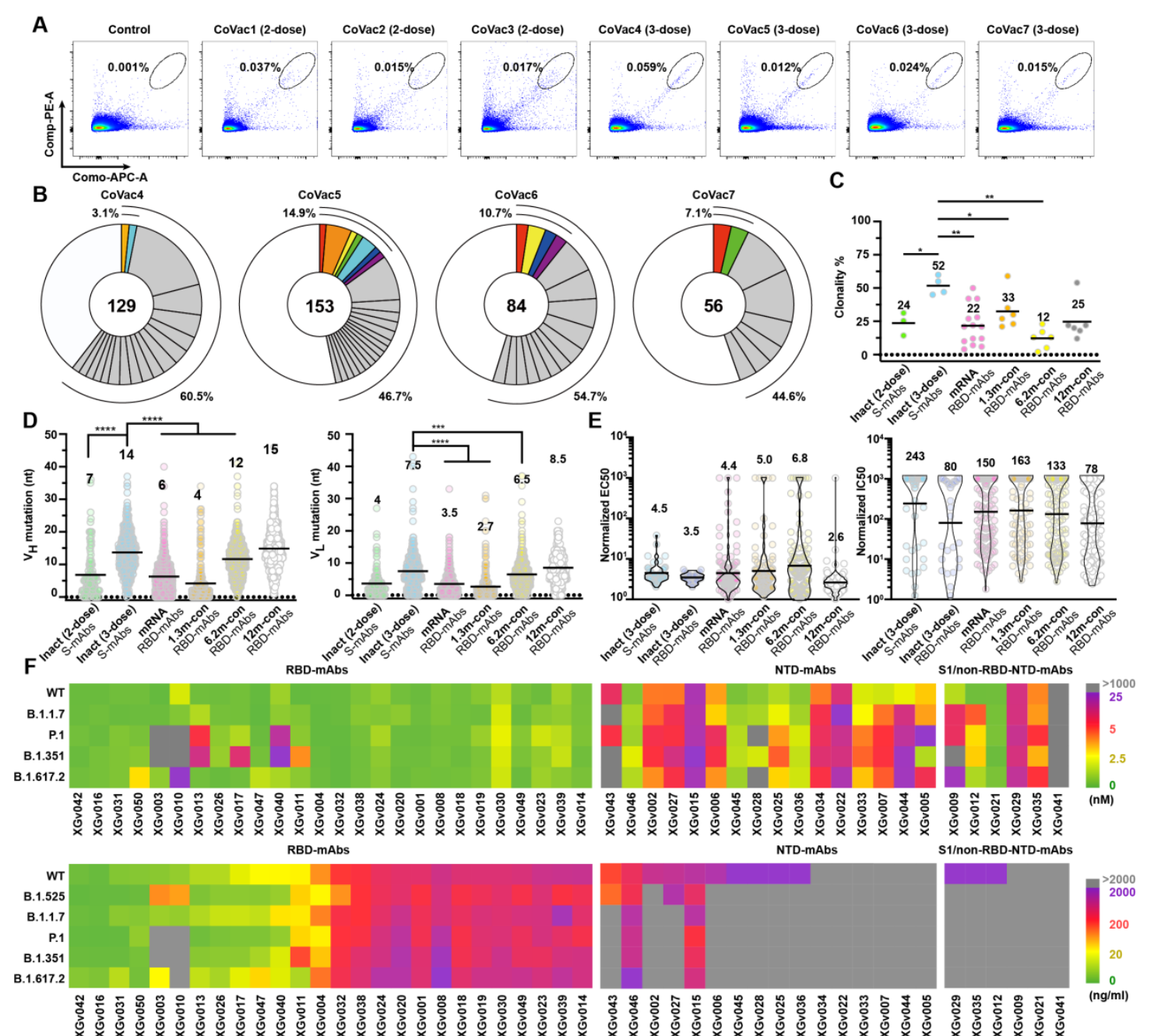

Fig. 2 Memory $B$ cell antibodies elicited by a $3^{\text {rd }}$-dose booster of an inactivated vaccine

571 (A) Representative flow cytometry plots showing dual allophycocyanin (APC)-S-

572 and phycoerythrin (PE)-S-binding B cells for vaccinees and control donor.

573 (B) Pie charts represent the distribution of antibody sequences from the four 3-dose 574 vaccinees. The number in the inner circle is the number of sequences analyzed here. 575 Pie-slice size is proportional to the number of clonally related sequences. The black 576 outline indicates the frequency of clonally expanded sequences detected individually. 577 Colored slices reveal clones that share the same IGHV and IGLV genes.

578 (C) Graph shows relative clonality among seven individuals who received 2-dose or 579 3-dose of inactivated vaccines. Relative clonality for COVID-19 convalescents 580 assayed at 1.3, 6.2 and 12 months after infection, as well as 2-dose mRNA vaccine 581 recipients $(2,14,18)$, previously described by Michel's group, was compared. Black 
medRxiv preprint doi: https://doi.org/10.1101/2021.09.02.21261735; this version posted September 5, 2021. The copyright holder for this preprint (which was not certified by peer review) is the author/funder, who has granted medRxiv a license to display the preprint in It is made available under a CC-BY 4.0 International license.

582 horizontal bars indicate mean values. Statistical significance was determined using 583 two-tailed t-test.

584 (D) Number of somatic nucleotide mutations in the IGHV (left) and IGLV (right) in 585 antibodies from vaccinees, including 2-dose or 3-dose of inactivated vaccines and 2586 dose of mRNA vaccines and COVID-19 convalescents assayed at 1.3, 6.2 and 12 587 months after infection $(2,14,18)$.

588 (E) Normalized ELISA binding $\left(\mathrm{EC}_{50}\right)$ by antibodies isolated from the 3-dose 589 inactivated and 2-dose mRNA vaccinees (ref) as well as COVID-19 convalescents to 590 SARS-CoV-2 S trimer (left) and normalized pseudovirus neutralization activity 591 (IC50) (right) against SARS-CoV-2 assayed at 1.3, 6.2 and 12 months after infection 592 (ref). Among these, eight antibodies reported by Michel's group were expressed and 593 assessed for both binding by ELISA and pseudovirus neutralization activity for 594 normalized comparison here. Black horizontal bars indicate mean values.

595 (F) BLI binding affinities (upper panel) and pseudo-typed virus neutralization 596 (bottom panel) by antibodies isolated from the 3-dose vaccinees to circulating SARS597 CoV-2 variants. Color gradient for upper panel indicates $K_{D}$ values ranging from 0 598 (green), through 2.5 (yellow) and 5 (red) to $25 \mathrm{nM}$ (purple). Gray suggests no/very 599 limited binding activity $(>1000 \mathrm{nM})$. Color gradient for bottom panel indicates $\mathrm{IC}_{50}$ 600 values ranging from 0 (green), through 20 (yellow) and 200 (red) to $2000 \mathrm{ng} / \mathrm{ml}$ 601 (purple). Gray suggests no/very limited neutralizing activity (>2000 ng/ml). 

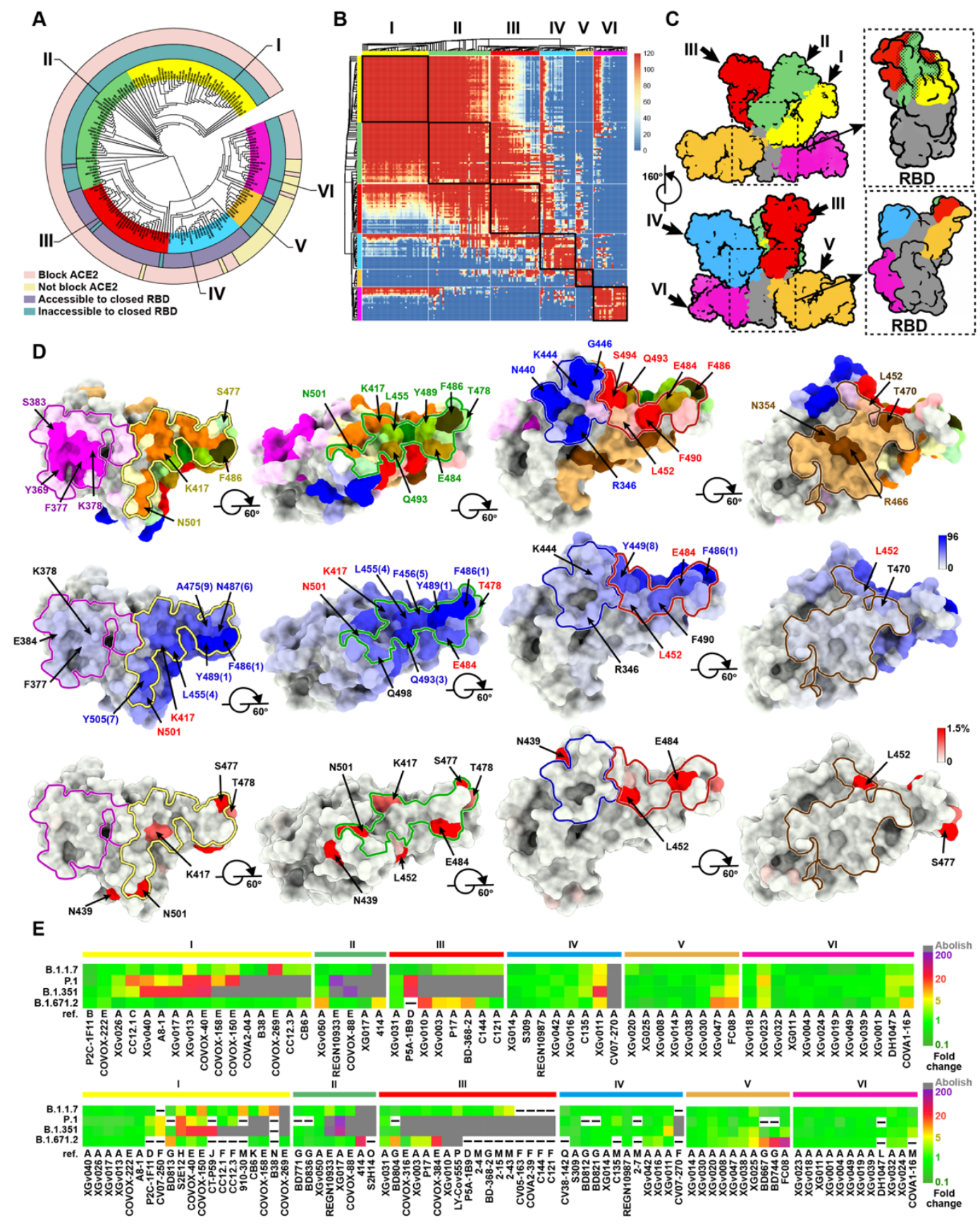

611 Fig. 3 Structural landscape and immunogenic features of RBD NAbs

612 (A) Structure-based antigenic clustering of SARS-CoV-2 RBD NAbs. A total of 171

613 RBD NAbs with available structures were classified into six clusters (I, II, III, IV, V

614 and VI). NAbs that can block ACE2 binding or not are outlined by light pink and

615 light yellow, respectively. NAbs that can attach to the closed RBD or not are outlined

616 by gray blue and gray green, respectively.

617 (B) Superimposition matrix of 171 RBD NAb structures' output from clashed areas

$618\left(\AA^{2}\right)$ between variable regions of any two Fab fragments showing the clustering into 
medRxiv preprint doi: https://doi.org/10.1101/2021.09.02.21261735; this version posted September 5, 2021. The copyright holder for this preprint (which was not certified by peer review) is the author/funder, who has granted medRxiv a license to display the preprint in

It is made available under a CC-BY 4.0 International license.

619 six antibody classes.

620 (C) Surface representative model of six types of NAbs bound to the RBD. Fab

621 fragments of six representative antibodies are shown in different colors and the RBD

622 is colored in gray. Insets illustrate the antigenic patches targeted by six representative

623 antibodies. Dashed dots indicate the overlaps between two adjacent antigenic 624 patches.

625 (D) Structural landscapes of the six classes of RBD NAbs (upper panel). Antigenic 626 patches (with targeting frequency $>30 \%$ ) recognized by six classes of NAbs are 627 outlined in the assigned color scheme (same to Fig. 3C), among which residues with 628 "hot targeting frequency" (generally over 65\%, but over $85 \%$ in class I) are shown 629 in bright colors corresponding to the patches they belong to. Residues involved in 630 two (such as Y489, L452) or three (such as F486) neighboring antigenic patches are 631 presented in a mixed color. Representative "hot" antigenic residues are labeled. 632 Middle: hot map for antigenic residues on the RBD. Per residue frequency 633 recognized by the 171 NAbs were calculated and shown. The top 9 of the hottest 634 antigenic residues and key residues with substitutions in several VOCs are marked 635 and labeled. Bottom: hot map for circulating variants with mutations on the RBD. 636 Mutation frequency for each residue was calculated based on the datasets from 637 GISAID.

638 (E) Immunogenic characteristics of six classes of RBD-targeting NAbs. Hot maps 639 show relative fold changes in $K_{D}$ values (up) and $\mathrm{IC}_{50}$ values (down) against several 640 VOCs for the six classes of NAbs, including previously reported (97-108) and newly 641 isolated antibodies described in this manuscript. Color gradients for upper and 642 bottom panels indicate relative fold changes and are shown at right side. "-": no 643 related datasets in the original studies and related references are listed. Ref "A" 644 indicates that the datasets were produced in this manuscript. Other letters in Ref 645 correspond to different reference numbers shown as below. B - 91 and this 646 manuscipt, $\mathrm{C}-99$ and this manuscript, D - 97, E - 30, 81, 103 and 104, F - 99, G $64798, \mathrm{H}-100$ and 108, J - 101, K - 94 and 102, L - 105 and 106, M - 94, N - 105, O 648 $-107, \mathrm{P}-82, \mathrm{Q}-66$, respectively. 

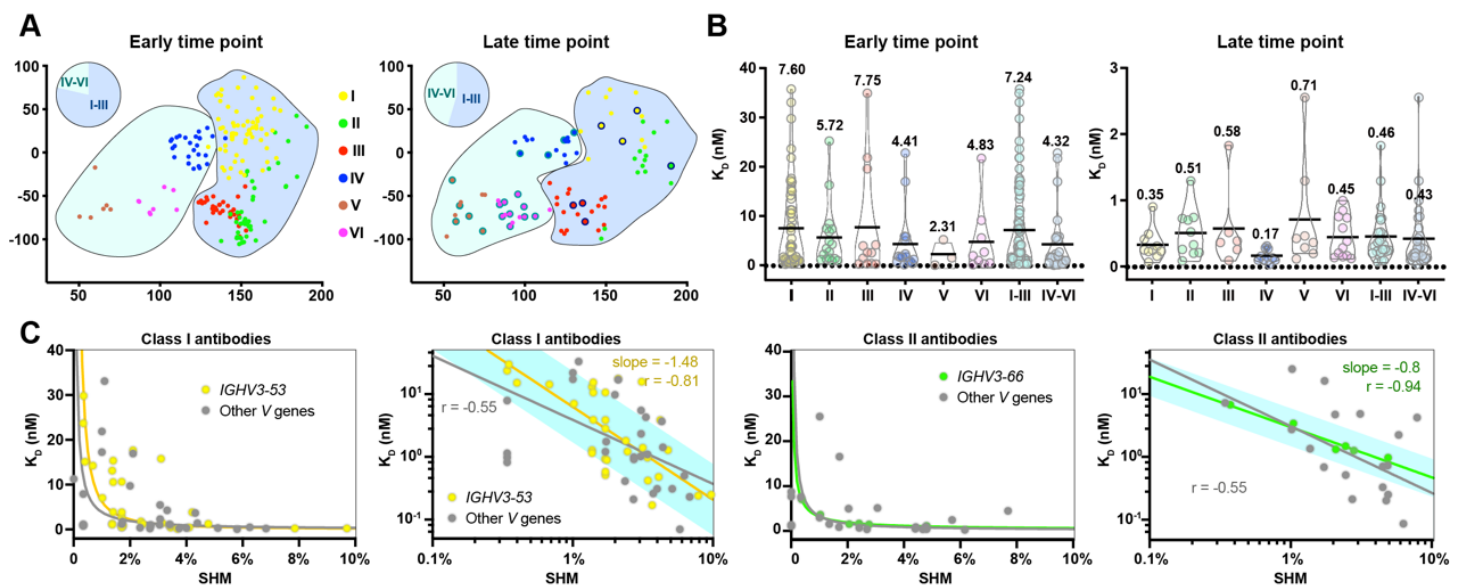

Fig. 4 Antibody evolution and affinity maturation

651

652

653

654

655

656

657

658

659

660

661

662

663

664

665

666

667

668

669

670

671

(A) Uniform manifold approximation and projection (UMAP) plot displaying the antibodies defined as the early time point group (left) and late time point group (right). The antibodies are colored based on their cluster assignments by the hierarchical clustering algorithm. Antibodies from I to III and IV to VI are highlighted in cyan and gray blue background, respectively. Pie charts represent the frequency distribution of antibodies belonging to I to III and IV to VI. Antibodies isolated from 3-dose vaccinees are outlined by black lines.

(B) Dissociation constants $\left(K_{\mathrm{D}}\right)$ of the antibodies from I to VI. Individual class antibodies are represented in colors corresponding to the classes they belong to. The color scheme is same as Fig. 4A. BLI traces are shown in fig. S9.

(C) The measured $K_{D^{-}}$SHM plots (left) and $K_{D^{-}}$SHM log-log plots (right) of antibodies from I and II are shown. IGHV3-53 and IGHV3-66 antibodies belonging to class I and II are colored in yellow and green, respectively. The straight curves and lines are the least squares fits of the data to the power law with the values of the slope for IGHV3-53 and IGHV3-66 antibodies. The black curves and lines indicate the fitting of antibodies from I or II; the yellow and green ones suggest the fitting of IGHV3-53 and IGHV3-66 antibodies, respectively. The cyan lines are the $90 \%$ predicted interval.

\section{References and Notes:}


medRxiv preprint doi: https://doi.org/10.1101/2021.09.02.21261735; this version posted September 5, 2021. The copyright holder for this preprint (which was not certified by peer review) is the author/funder, who has granted medRxiv a license to display the preprint in

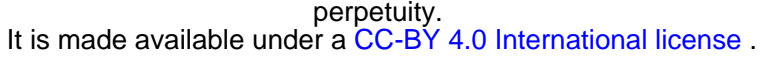

672 1. N. G. Davies, S. Abbott et al., Estimated transmissibility and impact of SARS-CoV-2 lineage

673 B.1.1.7 in England. Science 372, (2021); published online EpubApr 9 $674 \quad$ (10.1126/science.abg3055).

675 2. Z. Wang, F. Schmidt et al., mRNA vaccine-elicited antibodies to SARS-CoV-2 and

3. A. Muik, A. K. Wallisch et al., Neutralization of SARS-CoV-2 lineage B.1.1.7 pseudovirus

4. W. F. Garcia-Beltran, E. C. Lam et al., Multiple SARS-CoV-2 variants escape neutralization

5. E. Hacisuleyman, C. Hale et al., Vaccine Breakthrough Infections with SARS-CoV-2 Variants. N Engl J Med 384, 2212-2218 (2021); published online EpubJun 10 (10.1056/NEJMoa2105000).

6. E. C. Sabino, L. F. Buss et al., Resurgence of COVID-19 in Manaus, Brazil, despite high seroprevalence. Lancet 397, 452-455 (2021); published online EpubFeb 6 (10.1016/S0140-6736(21)00183-5).

7. W. N. Chia, F. Zhu et al., Dynamics of SARS-CoV-2 neutralising antibody responses and duration of immunity: a longitudinal study. The Lancet. Microbe 2, e240-e249 (2021); published online EpubJun (10.1016/S2666-5247(21)00025-2).

8. A. T. Widge, N. G. Rouphael et al., Durability of Responses after SARS-CoV-2 mRNA-1273 Vaccination. N Engl J Med 384, 80-82 (2021); published online EpubJan 7 (10.1056/NEJMc2032195).

9. Y. Zhang, G. Zeng et al., Safety, tolerability, and immunogenicity of an inactivated SARSCoV-2 vaccine in healthy adults aged 18-59 years: a randomised, double-blind, placebocontrolled, phase 1/2 clinical trial. Lancet Infect Dis 21, 181-192 (2021); published online EpubFeb (10.1016/S1473-3099(20)30843-4).

10. Q. Gao, L. Bao et al., Development of an inactivated vaccine candidate for SARS-CoV-2. Science 369, 77-81 (2020); published online EpubJul 3 (10.1126/science.abc1932).

11. D. S. Khoury, A. K. Wheatley et al., Measuring immunity to SARS-CoV-2 infection: comparing assays and animal models. Nature reviews. Immunology 20, 727-738 (2020); published online EpubDec (10.1038/s41577-020-00471-1).

12. L. Riepler, A. Rossler et al., Comparison of Four SARS-CoV-2 Neutralization Assays. Vaccines 9, (2020); published online EpubDec 28 (10.3390/vaccines9010013).

13. Q. W. Hongxing Pan, G. Zeng, Immunogenicity and safety of a third dose, and immune persistence of CoronaVac vaccine in healthy adults aged 18-59 years: interim results from a double-blind, randomized, placebo-controlled phase 2 clinical trial. medRxiv, (2021)https://doi.org/10.1101/2021.07.23.21261026).

14. Z. Wang, F. Muecksch et al., Naturally enhanced neutralizing breadth against SARS-CoV2 one year after infection. Nature 595, 426-431 (2021); published online EpubJul (10.1038/s41586-021-03696-9).

15. F. Muecksch, Y. Weisblum et al., Development of potency, breadth and resilience to viral escape mutations in SARS-CoV-2 neutralizing antibodies. bioRxiv, (2021); published online EpubMar 8 (10.1101/2021.03.07.434227).

16. C. Gaebler, Z. Wang et al., Evolution of antibody immunity to SARS-CoV-2. Nature 591, 639-644 (2021); published online EpubMar (10.1038/s41586-021-03207-w).

17. Y. Zhou, Z. Liu et al., Enhancement versus neutralization by SARS-CoV-2 antibodies from a convalescent donor associates with distinct epitopes on the RBD. Cell Rep 34, 108699 (2021); published online EpubFeb 2 (10.1016/j.celrep.2021.108699).

18. D. F. Robbiani, C. Gaebler et al., Convergent antibody responses to SARS-CoV-2 in convalescent individuals. Nature 584, 437-442 (2020); published online EpubAug 
(10.1038/s41586-020-2456-9).

19. A. C. Walls, Y. J. Park et al., Structure, Function, and Antigenicity of the SARS-CoV-2 Spike Glycoprotein. Cell 181, 281-292 e286 (2020); published online EpubApr 16 (10.1016/j.cell.2020.02.058).

20. D. Wrapp, N. Wang et al., Cryo-EM structure of the 2019-nCoV spike in the prefusion conformation. Science 367, 1260-1263 (2020); published online EpubMar 13 (10.1126/science.abb2507).

21. R. Yan, R. Wang et al., Structural basis for bivalent binding and inhibition of SARS-CoV-2 infection by human potent neutralizing antibodies. Cell Res 31, 517-525 (2021); published online EpubMay (10.1038/s41422-021-00487-9).

22. W. Dejnirattisai, D. Zhou et al., The antigenic anatomy of SARS-CoV-2 receptor binding domain. Cell 184, 2183-2200 e2122 (2021); published online EpubApr 15 (10.1016/j.cell.2021.02.032).

23. M. Yuan, H. Liu et al., Structural basis of a shared antibody response to SARS-CoV-2. Science 369, 1119-1123 (2020); published online EpubAug 28 (10.1126/science.abd2321).

24. F. Bertoglio, V. Fuhner et al., A SARS-CoV-2 neutralizing antibody selected from COVID19 patients binds to the ACE2-RBD interface and is tolerant to most known RBD mutations. Cell Rep 36, 109433 (2021); published online EpubJul 27 (10.1016/j.celrep.2021.109433).

25. S. A. Clark, L. E. Clark et al., Molecular basis for a germline-biased neutralizing antibody response to SARS-CoV-2. bioRxiv, (2020); published online EpubNov 13 $(10.1101 / 2020.11 .13 .381533)$.

26. B. B. Banach, G. Cerutti et al., Paired heavy and light chain signatures contribute to potent SARS-CoV-2 neutralization in public antibody responses. bioRxiv, (2021); published online EpubJan 3 (10.1101/2020.12.31.424987).

27. B. E. Jones, P. L. Brown-Augsburger et al., The neutralizing antibody, LY-CoV555, protects against SARS-CoV-2 infection in nonhuman primates. Sci Trans/ Med 13, (2021); published online EpubMay 12 (10.1126/scitranslmed.abf1906).

28. Y. Guo, L. Huang et al., A SARS-CoV-2 neutralizing antibody with extensive Spike binding coverage and modified for optimal therapeutic outcomes. Nat Commun 12, 2623 (2021); published online EpubMay 11 (10.1038/s41467-021-22926-2).

29. S. Du, Y. L. Cao et al., Structurally Resolved SARS-CoV-2 Antibody Shows High Efficacy in Severely Infected Hamsters and Provides a Potent Cocktail Pairing Strategy. Cel/ 183, 1013-+ (2020); published online EpubNov 12 (10.1016/j.cell.2020.09.035).

30. W. Dejnirattisai, D. M. Zhou et al., Antibody evasion by the P.1 strain of SARS-CoV-2. Cell 184, 2939-+ (2021); published online EpubMay 27 (10.1016/j.cell.2021.03.055).

31. C. O. Barnes, C. A. Jette et al., SARS-CoV-2 neutralizing antibody structures inform therapeutic strategies. Nature 588, 682-+ (2020); published online EpubDec 24 (10.1038/s41586-020-2852-1).

32. N. C. Wu, M. Yuan et al., An Alternative Binding Mode of IGHV3-53 Antibodies to the SARS-CoV-2 Receptor Binding Domain. Cell Reports 33, (2020); published online EpubOct 20 (10.1016/J.Celrep.2020.108274).

33. H. J. Liu, N. C. Wu et al., Cross-Neutralization of a SARS-CoV-2 Antibody to a Functionally Conserved Site Is Mediated by Avidity. Immunity 53, 1272-+ (2020); published online EpubDec 15 (10.1016/j.immuni.2020.10.023).

34. N. K. Hurlburt, E. Seydoux et al., Structural basis for potent neutralization of SARS-CoV-2 and role of antibody affinity maturation. Nature Communications 11, (2020); published online EpubOct 27 (10.1038/S41467-020-19231-9).

35. Y. Wu, F. R. Wang et al., A noncompeting pair of human neutralizing antibodies block COVID-19 virus binding to its receptor ACE2. Science 368, 1274-+ (2020); published online EpubJun 12 (10.1126/science.abc2241). 
36. R. Shi, C. Shan et al., A human neutralizing antibody targets the receptor-binding site of SARS-CoV-2. Nature 584, 120-+ (2020); published online EpubAug 6 (10.1038/s41586020-2381-y).

37. J.W. Ge, R. K. Wang et al., Antibody neutralization of SARS-CoV-2 through ACE2 receptor mimicry. Nature Communications 12, (2021); published online EpubJan 11 (10.1038/s41467-020-20501-9).

38. C. O. Barnes, A. P. West et al., Structures of Human Antibodies Bound to SARS-CoV-2 Spike Reveal Common Epitopes and Recurrent Features of Antibodies. Cel/ 182, 828-+ (2020); published online EpubAug 20 (10.1016/j.cell.2020.06.025).

39. H. P. Yao, Y. Sun et al., Rational development of a human antibody cocktail that deploys multiple functions to confer Pan-SARS-CoVs protection. Cell Research 31, 25-36 (2021); published online EpubJan (10.1038/s41422-020-00444-y).

40. N. Wang, Y. Sun et al., Structure-based development of human antibody cocktails against SARS-CoV-2. Cell Research 31, 101-103 (2021); published online EpubJan (10.1038/s41422-020-00446-w).

41. S. Miersch, Z. Li, Tetravalent SARS-CoV-2 Neutralizing Antibodies Show Enhanced Potency and Resistance to Escape Mutations. BioRxiv, (2021)https://doi.org/10.1101/2020.10.31.362848).

42. C. J. Bracken, S. A. Lim et al., Bi-paratopic and multivalent VH domains block ACE2 binding and neutralize SARS-CoV-2. Nature chemical biology 17, 113-121 (2021); published online EpubJan (10.1038/s41589-020-00679-1).

43. C. Zhang, Y. F. Wang et al., Development and structural basis of a two-MAb cocktail for treating SARS-CoV-2 infections. Nature Communications 12, (2021); published online EpubJan 11 (10.1038/s41467-020-20465-w).

44. L. Piccoli, Y. J. Park et al., Mapping Neutralizing and Immunodominant Sites on the SARSCoV-2 Spike Receptor-Binding Domain by Structure-Guided High-Resolution Serology. Cel/ 183, 1024-+ (2020); published online EpubNov 12 (10.1016/j.cell.2020.09.037).

45. J. Hansen, A. Baum et al., Studies in humanized mice and convalescent humans yield a SARS-CoV-2 antibody cocktail. Science 369, 1010-1014 (2020); published online EpubAug 21 (10.1126/science.abd0827).

46. J. Kreye, S. M. Reincke et al., A Therapeutic Non-self-reactive SARS-CoV-2 Antibody Protects from Lung Pathology in a COVID-19 Hamster Model. Ce// 183, 1058-+ (2020); published online EpubNov 12 (10.1016/j.cell.2020.09.049).

47. R. Rouet, O. Mazigi et al., Potent SARS-CoV-2 binding and neutralization through maturation of iconic SARS-CoV-1 antibodies. Mabs-Austin 13, (2021); published online EpubJan 1 (10.1080/19420862.2021.1922134).

48. M. A. Tortorici, M. Beltramello et al., Ultrapotent human antibodies protect against SARSCoV-2 challenge via multiple mechanisms. Science 370, 950-+ (2020); published online EpubNov 20 (10.1126/science.abe3354).

49. E. Rujas, I. Kucharska et al., Multivalency transforms SARS-CoV-2 antibodies into ultrapotent neutralizers. Nature Communications 12, (2021); published online EpubJun 16 (10.1038/S41467-021-23825-2).

50. J. Ahmad, J. Jiang et al., Synthetic nanobody-SARS-CoV-2 receptor-binding domain structures identify distinct epitopes. bioRxiv, (2021); published online EpubJan 27 (10.1101/2021.01.27.428466).

51. M. Schoof, B. Faust et al., An ultrapotent synthetic nanobody neutralizes SARS-CoV-2 by stabilizing inactive Spike. Science 370, 1473-1479 (2020); published online EpubDec 18 (10.1126/science.abe3255).

52. M. Rapp, Y. C. Guo et al., Modular basis for potent SARS-CoV-2 neutralization by a prevalent VH1-2-derived antibody class. Cell Reports 35, (2021); published online EpubApr 6 (10.1016/J.Celrep.2021.108950). 
53. C. Kim, D. K. Ryu et al., A therapeutic neutralizing antibody targeting receptor binding domain of SARS-CoV-2 spike protein. Nature Communications 12, (2021); published online EpubJan 12 (10.1038/s41467-020-20602-5).

54. D. Li, R. J. Edwards et al., In vitro and in vivo functions of SARS-CoV-2 infection-enhancing and neutralizing antibodies. Cell, (2021); published online EpubJun 18 (10.1016/j.cell.2021.06.021).

55. L. Hanke, L. V. Perez et al., An alpaca nanobody neutralizes SARS-CoV-2 by blocking receptor interaction. Nature Communications 11, (2020); published online EpubSep 4 (10.1038/S41467-020-18174-5).

56. J. D. Huo, A. Le Bas et al., Neutralizing nanobodies bind SARS-CoV-2 spike RBD and block interaction with ACE2 (vol 27, pg 846, 2020). Nature Structural \& Molecular Biology 28, 326-326 (2021); published online EpubMar (10.1038/s41594-021-00566-w).

57. B. Ju, Q. Zhang et al., Human neutralizing antibodies elicited by SARS-CoV-2 infection. Nature 584, 115-+ (2020); published online EpubAug 6 (10.1038/s41586-020-2380-z).

58. Y. L. Cao, B. Su et al., Potent Neutralizing Antibodies against SARS-CoV-2 Identified by High-Throughput Single-Cell Sequencing of Convalescent Patients' B Cells. Cel/ 182, 73+ (2020); published online EpubJul 9 (10.1016/j.cell.2020.05.025).

59. L. H. Liu, P. F. Wang et al., Potent neutralizing antibodies against multiple epitopes on SARS-CoV-2 spike. Nature 584, 450-+ (2020); published online EpubAug 20 (10.1038/s41586-020-2571-7).

60. P. A. Koenig, H. Das et al., Structure-guided multivalent nanobodies block SARS-CoV-2 infection and suppress mutational escape. Science 371, 691-+ (2021); published online EpubFeb 12 (10.1126/science.abe6230).

61. Y. F. Xiang, S. Nambulli et al., Versatile and multivalent nanobodies efficiently neutralize SARS-CoV-2. Science 370, 1479-1484 (2020); published online EpubDec 18 (10.1126/science.abe4747).

62. L. Zhu, Y. Q. Deng et al., Double lock of a potent human therapeutic monoclonal antibody against SARS-CoV-2. National Science Review 8, (2021); published online EpubMar (10.1093/nsr/nwaa297).

63. G. Cerutti, M. Rapp et al., Structural basis for accommodation of emerging B.1.351 and B.1.1.7 variants by two potent SARS-CoV-2 neutralizing antibodies. Structure 29, 655-+ (2021); published online EpubJul 1 (10.1016/j.str.2021.05.014).

64. T. F. Custodio, H. Das et al., Selection, biophysical and structural analysis of synthetic nanobodies that effectively neutralize SARS-CoV-2. Nature Communications 11, (2020); published online EpubNov 4 (10.1038/S41467-020-19204-Y).

65. J. F. Scheid, C. O. Barnes et al., B cell genomics behind cross-neutralization of SARS-CoV2 variants and SARS-CoV. Cell 184, 3205-+ (2021); published online EpubJun 10 (10.1016/j.cell.2021.04.032).

66. H. J. Liu, M. Yuan et al., A combination of cross-neutralizing antibodies synergizes to prevent SARS-CoV-2 and SARS-CoV pseudovirus infection. Cell Host \& Microbe 29, 806+ (2021); published online EpubMay 12 (10.1016/j.chom.2021.04.005).

67. D. Pinto, Y. J. Park et al., Cross-neutralization of SARS-CoV-2 by a human monoclonal SARS-CoV antibody. Nature 583, 290-295 (2020); published online EpubJul (10.1038/s41586-020-2349-y).

68. T. N. Starr, N. Czudnochowski et al., Antibodies to the SARS-CoV-2 receptor-binding domain that maximize breadth and resistance to viral escape. bioRxiv, (2021).

69. D. M. Zhou, H. M. E. Duyvesteyn et al., Structural basis for the neutralization of SARSCoV-2 by an antibody from a convalescent patient. Nature Structural \& Molecular Biology 27, 950-+ (2020); published online EpubOct (10.1038/s41594-020-0480-y).

70. M. Yuan, N. C. Wu et al., A highly conserved cryptic epitope in the receptor binding domains of SARS-CoV-2 and SARS-CoV. Science 368, 630-+ (2020); published online 
EpubMay 8 (10.1126/science.abb7269).

71. Z. LV, Y. Q. Deng et al., Structural basis for neutralization of SARS-CoV-2 and SARS-CoV by a potent therapeutic antibody. Science 369, 1505-+ (2020); published online EpubSep 18 (10.1126/science.abc5881).

72. Y. L. Cao, A. Yisimayi et al., Humoral immune response to circulating SARS-CoV-2 variants elicited by inactivated and RBD-subunit vaccines. Cell Research 31, 732-741 (2021); published online EpubJul (10.1038/s41422-021-00514-9).

73. Y. Sun, L. Wang et al., Structure-based development of three- and four-antibody cocktails against SARS-CoV-2 via multiple mechanisms. Cell Research 31, 597-600 (2021); published online EpubMay (10.1038/s41422-021-00497-7).

74. X. Zhu, D. Mannar et al., Cryo-electron microscopy structures of the N501Y SARS-CoV-2 spike protein in complex with ACE2 and 2 potent neutralizing antibodies. PLOS Bio/ 19, e3001237 (2021); published online EpubApr (10.1371/journal.pbio.3001237).

75. D. Asarnow, B. Wang et al., Structural insight into SARS-CoV-2 neutralizing antibodies and modulation of syncytia. Cell 184, 3192-+ (2021); published online EpubJun 10 (10.1016/j.cell.2021.04.033).

76. X. J. Zhou, F. G. Ma et al., Diverse immunoglobulin gene usage and convergent epitope targeting in neutralizing antibody responses to SARS-CoV-2. Cell Reports 35, (2021); published online EpubMay 11 (10.1016/j.celrep.2021.109109).

77. M. F. Jennewein, A. J. MacCamy et al., Isolation and characterization of cross-neutralizing coronavirus antibodies from COVID-19+ subjects. Cell Rep 36, 109353 (2021); published online EpubJul 13 (10.1016/j.celrep.2021.109353).

78. T. N. Starr, N. Czudnochowski et al., SARS-CoV-2 RBD antibodies that maximize breadth and resistance to escape. Nature, 1-9 (2021).

79. J. Fedry, D. L. Hurdiss et al., Structural insights into the cross-neutralization of SARS-CoV and SARS-CoV-2 by the human monoclonal antibody 47D11. Science Advances 7, (2021); published online EpubJun (10.1126/sciadv.abf5632).

80. K. Westendorf, S. Zentelis et al., LY-CoV1404 potently neutralizes SARS-CoV-2 variants. bioRxiv, (2021); published online EpubMay 4 (10.1101/2021.04.30.442182).

81. C. Liu, H. M. Ginn et al., Reduced neutralization of SARS-CoV-2 B.1.617 by vaccine and convalescent serum. Cell, (2021); published online EpubJun 17 (10.1016/j.cell.2021.06.020).

82. L. Wang, T. Zhou et al., Ultrapotent antibodies against diverse and highly transmissible SARS-CoV-2 variants. Science, (2021); published online EpubJul 1 (10.1126/science.abh1766).

83. L. Zhang, L. Cao et al., A proof of concept for neutralizing antibody-guided vaccine design against SARS-CoV-2. National Science Review, (2020)10.1093/nsr/nwab053).

84. J. Huo, Y. Zhao et al., Neutralization of SARS-CoV-2 by Destruction of the Prefusion Spike. Cell Host Microbe 28, 445-454 e446 (2020); published online EpubSep 9 (10.1016/j.chom.2020.06.010).

85. M. McCallum, A. De Marco et al., N-terminal domain antigenic mapping reveals a site of vulnerability for SARS-CoV-2. Cell 184, 2332-2347 e2316 (2021); published online EpubApr 29 (10.1016/j.cell.2021.03.028).

86. G. Cerutti, Y. Guo et al., Potent SARS-CoV-2 neutralizing antibodies directed against spike $\mathrm{N}$-terminal domain target a single supersite. Cell Host Microbe 29, 819-833 e817 (2021); published online EpubMay 12 (10.1016/j.chom.2021.03.005).

87. X. Y. Chi, R. H. Yan et al., A neutralizing human antibody binds to the N-terminal domain of the Spike protein of SARS-CoV-2. Science 369, 650-+ (2020); published online EpubAug 7 (10.1126/science.abc6952).

88. W. N. Voss, Y. X. J. Hou et al., Prevalent, protective, and convergent IgG recognition of SARS-CoV-2 non-RBD spike epitopes. Science 372, 1108-+ (2021); published online 
medRxiv preprint doi: https://doi.org/10.1101/2021.09.02.21261735; this version posted September 5, 2021. The copyright holder for this preprint (which was not certified by peer review) is the author/funder, who has granted medRxiv a license to display the preprint in

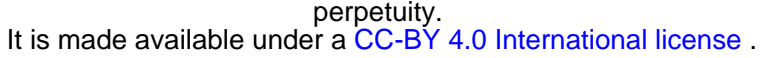

EpubJun 4 (10.1126/science.abg5268).

89. A. Rosa, V. E. Pye et al., SARS-CoV-2 can recruit a heme metabolite to evade antibody immunity. Science Advances 7, (2021); published online EpubMay (10.1126/sciadv.abg7607).

90. Y. F. Liu, W. T. Soh et al,, An infectivity-enhancing site on the SARS-CoV-2 spike protein targeted by antibodies. Cell 184, 3452-+ (2021); published online EpubJun 24 (10.1016/j.cell.2021.05.032).

91. P. J. M. Brouwer, T. G. Caniels et al., Potent neutralizing antibodies from COVID-19 patients define multiple targets of vulnerability. Science 369, 643-+ (2020); published online EpubAug 7 (10.1126/science.abc5902).

92. T. Noy-Porat, A. Mechaly et al., Therapeutic antibodies, targeting the SARS-CoV-2 spike $\mathrm{N}$-terminal domain, protect lethally infected K18-hACE2 mice. Iscience 24, (2021); published online EpubMay 21 (10.1016/j.isci.2021.102479).

93. J. Goike, C. L. Hsieh et al., Synthetic repertoires derived from convalescent COVID-19 patients enable discovery of SARS-CoV-2 neutralizing antibodies and a novel quaternary binding modality. bioRxiv, (2021); published online EpubApr 9 (10.1101/2021.04.07.438849).

94. P. Wang, M. S. Nair et al., Antibody resistance of SARS-CoV-2 variants B.1.351 and B.1.1.7. Nature 593, 130-135 (2021); published online EpubMay (10.1038/s41586-021-03398-2).

95. J. Lopez Bernal, N. Andrews et al., Effectiveness of Covid-19 Vaccines against the B.1.617.2 (Delta) Variant. N Engl J Med, (2021); published online EpubJul 21 (10.1056/NEJMoa2108891).

96. A. Sheikh, J. McMenamin et al., SARS-CoV-2 Delta VOC in Scotland: demographics, risk of hospital admission, and vaccine effectiveness. Lancet 397, 2461-2462 (2021); published online EpubJun 26 (10.1016/S0140-6736(21)01358-1).

97. R. Wang, Q. Zhang et al., Analysis of SARS-CoV-2 variant mutations reveals neutralization escape mechanisms and the ability to use ACE2 receptors from additional species. Immunity 54, 1611-1621 e1615 (2021); published online EpubJul 13 (10.1016/j.immuni.2021.06.003).

98. P. L. Shuo Du, Zhiying Zhang, Structures of SARS-CoV-2 B.1.351 neutralizing antibodies provide insights into cocktail design against concerning variants. bioRxiv, (2021)https://doi.org/10.1101/2021.07.30.454402).

99. M. Yuan, D. Huang et al., Structural and functional ramifications of antigenic drift in recent SARS-CoV-2 variants. Science, (2021); published online EpubMay 20 (10.1126/science.abh1139).

100. R. T. E. Chen, X. W. Zhang et al., Resistance of SARS-CoV-2 variants to neutralization by monoclonal and serum-derived polyclonal antibodies. Nature Medicine 27, (2021); published online EpubApr (10.1038/s41591-021-01294-w).

101. D. K. Ryu, R. Song et al., Therapeutic effect of CT-P59 against SARS-CoV-2 South African variant. Biochem Biophys Res Commun 566, 135-140 (2021); published online EpubAug 20 (10.1016/j.bbrc.2021.06.016).

102. P. Wang, R. G. Casner et al., Increased resistance of SARS-CoV-2 variant P.1 to antibody neutralization. Cell Host Microbe 29, 747-751 e744 (2021); published online EpubMay 12 (10.1016/j.chom.2021.04.007).

103. D. Zhou, W. Dejnirattisai et al., Evidence of escape of SARS-CoV-2 variant B.1.351 from natural and vaccine-induced sera. Cel/ 184, 2348-2361 e2346 (2021); published online EpubApr 29 (10.1016/j.cell.2021.02.037).

104. P. Supasa, D. Zhou et al., Reduced neutralization of SARS-CoV-2 B.1.1.7 variant by convalescent and vaccine sera. Cell 184, 2201-2211 e2207 (2021); published online EpubApr 15 (10.1016/j.cell.2021.02.033).

105. X. Y. Shen, H. L. Tang et al., SARS-CoV-2 variant B.1.1.7 is susceptible to neutralizing 
medRxiv preprint doi: https://doi.org/10.1101/2021.09.02.21261735; this version posted September 5, 2021. The copyright holder for this preprint (which was not certified by peer review) is the author/funder, who has granted medRxiv a license to display the preprint in

perpetuity.
It is made available under a CC-BY 4.0 International license .

989

990

991

992

993

994

995

996

997

998

999

1000

1001

1002

1003

1004

1005

1006

1007

1008

1009

1010

1011

1012

antibodies elicited by ancestral spike vaccines. Cell Host \& Microbe 29, 529-+ (2021); published online EpubApr 14 (10.1016/j.chom.2021.03.002).

106. D. R. Martinez, A. Schaefer et al., A broadly neutralizing antibody protects against SARSCoV, pre-emergent bat CoVs, and SARS-CoV-2 variants in mice. bioRxiv, (2021); published online EpubApr 28 (10.1101/2021.04.27.441655).

107. D. A. Collier, A. De Marco et al., Sensitivity of SARS-CoV-2 B.1.1.7 to mRNA vaccineelicited antibodies. Nature 593, 136-141 (2021); published online EpubMay (10.1038/s41586-021-03412-7).

108. R. E. Chen, E. S. Winkler et al., In vivo monoclonal antibody efficacy against SARS-CoV-2 variant strains. Nature, (2021); published online EpubJun 21 (10.1038/s41586-02103720-y). 